\title{
Seismic and non-seismic soft-sediment deformation structures in the Proterozoic Bhander Limestone, central India
}

\author{
Subir Sarkar ${ }^{1,}{ }^{*}$, Adrita Choudhuri ${ }^{1}$, Santanu Banerjee ${ }^{2}$, A.J. (Tom) van Loon ${ }^{3}$, \\ Pradip K. Bose ${ }^{1}$ \\ ${ }^{1}$ Department of Geological Sciences, Jadavpur University, Kolkata-700 032, India \\ ${ }^{2}$ Department of Earth Sciences, IIT Bombay, Powai, Mumbai 400 076, India \\ ${ }^{3}$ Institute of Geology, Adam Mickiewicz University, Maków Polnych 16, 61-606 Poznan, Poland; \\ e-mail: tvanloon@amu.edu.pl; tom.van.loon@wxs.nl \\ * corresponding author; e-mail: jugeoss@gmail.com
}

\begin{abstract}
Numerous soft-sediment deformation structures occur within the Proterozoic Bhander Limestone of an intracratonic sag basin in a $750 \mathrm{~m}$ long section along the Thomas River, near Maihar, central India. Part of these deformation structures have most probably a non-seismic origin, but other structures are interpreted as resulting from earthquake-induced shocks. These seismic structures are concentrated in a $60 \mathrm{~cm}$ thick interval, which is interpreted as three stacked seismites. These three seismites are traceable over the entire length of the section. They divide the sedimentary succession in a lower part (including the seismites) deposited in a hypersaline lagoon, and an upper open-marine (shelf) part. Most of the soft-sediment deformations outside the seismite interval occur in a lagoonal intraclastic and muddy facies association.

The SSDS within the seismite interval show a lateral continuity. They record simultaneous fluidisation and liquefaction. The bases of each of the three composing seismite bands are defined by small-scale shear folds, probably recording an earthquake and aftershocks.

The presence of the three seismite bands at the boundary between the lagoonal and the overlying open-marine oolitic facies association suggests that the seismic event also triggered basin subsidence.
\end{abstract}

Keywords: seismites, soft-sediment deformation structures, basin subsidence, Bhander Limestone, Proterozoic, India

\section{Introduction}

Non-biogenic processes that can trigger the genesis of soft-sediment deformation structures (SSDS) include unstable density gradients, wave loading, sediment overloading, undercutting, oversteepening, seismicity and many more (Seth et al., 1990). The structures produced are not, however, diagnostic for any of these processes (Van Loon, 2009; Van Loon et al., 2013). Moreover, SSDS of a particular geometry can be generated by different unrelated processes (Davies \& Gibling, 2003; Campbell et al., 2006; Chen et al., 2009; Van Loon, 2009; Owen et al., 2011). This makes the search for an unambiguous rock record of seismicity difficult although seismicity-related SSDS are commonly bounded to specific stratigraphical intervals and are laterally extensive (Seth et al., 1990). The SSDS in seismites may differ in form, size and intensity, however, because different types of unconsolidated sediment react in different ways to the earthquake-induced shock waves. Besides, the proximity to the epicentre, differential 
loading, the thickness of the deformed layers and several other factors have important roles to play.

The present contribution sifts out seismites out of numerous SSDS present in the Proterozoic Bhander Limestone (part of the Bhander Formation) of the Vindhyan Supergroup (Fig. 1) in central India. The seismically induced SSDS - previously called 'seismites' (Seilacher, 1984), an unfortunate use of the term (Van Loon, 2014a) - in the affected level are interesting not only because they occur within carbonate rocks, but also because the accumulation of the sediments took place in an intracratonic sag ba$\sin$. It pertains to the facts that carbonate sedimentation is, in general, discouraged in active basins, and intracratonic sag basins are least active tectonically. Also interesting is that the three SSDS-rich seismite bands occur on top of a succession with numerous SSDS of comparatively small dimensions, often with an uncertain but probably non-seismic origin. The probable processes and triggers responsible for these non-seismic SSDS as well as the deformational processes responsible for the SSDS in the seismites are here described and reconstructed.

Our study applied facies analysis to identify the depositional setting of the sediments that underwent deformation. The field work was carried out in a $750 \mathrm{~m}$ long section along the steep banks of the Thomas River, near the town of Maihar in Madhya Pradesh, India (Fig. 1).

\section{Geological background}

The Bhander Limestone Member of the Bhander Formation is approx. $90 \mathrm{~m}$ thick and forms part of the Vindhyan Supergroup (Fig. 1). The Lower Vindhyan Group formed within an intracratonic rift basin (Bose et al., 1997, 2001; Chakraborty, 2011) and the Upper Vindhyan Group, to which the Bhander Formation belongs, within an intracratonic sag basin (Sarkar et al., 2002).

The age of this formation is uncertain. Previous consensus was that it was less than $600 \mathrm{Ma}$ old (Bose et al., 2001, 2012; Ray et al., 2003; Ray 2006) but more recent works suggest a probable age $\sim 1000$ Ma (Malone et al., 2008; Gopalan et al., 2013; Venkateswaralu \& Rao, 2013). The complete absence of skeletal fossils in the Vindhyan Supergroup as a whole strongly suggests that the SSDS have no or at most an insignificant biogenic origin.

\subsection{Depositional setting}

The Bhander Limestone extends over several thousands of square kilometres in central India and is considered as marine (Chanda \& Bhattacharya, 1982; Akhtar, 1996; Sarkar et al., 1996), but this interpretation is, despite the abundance of wave-induced structures and $\delta^{13} \mathrm{C}$ values around zero, still

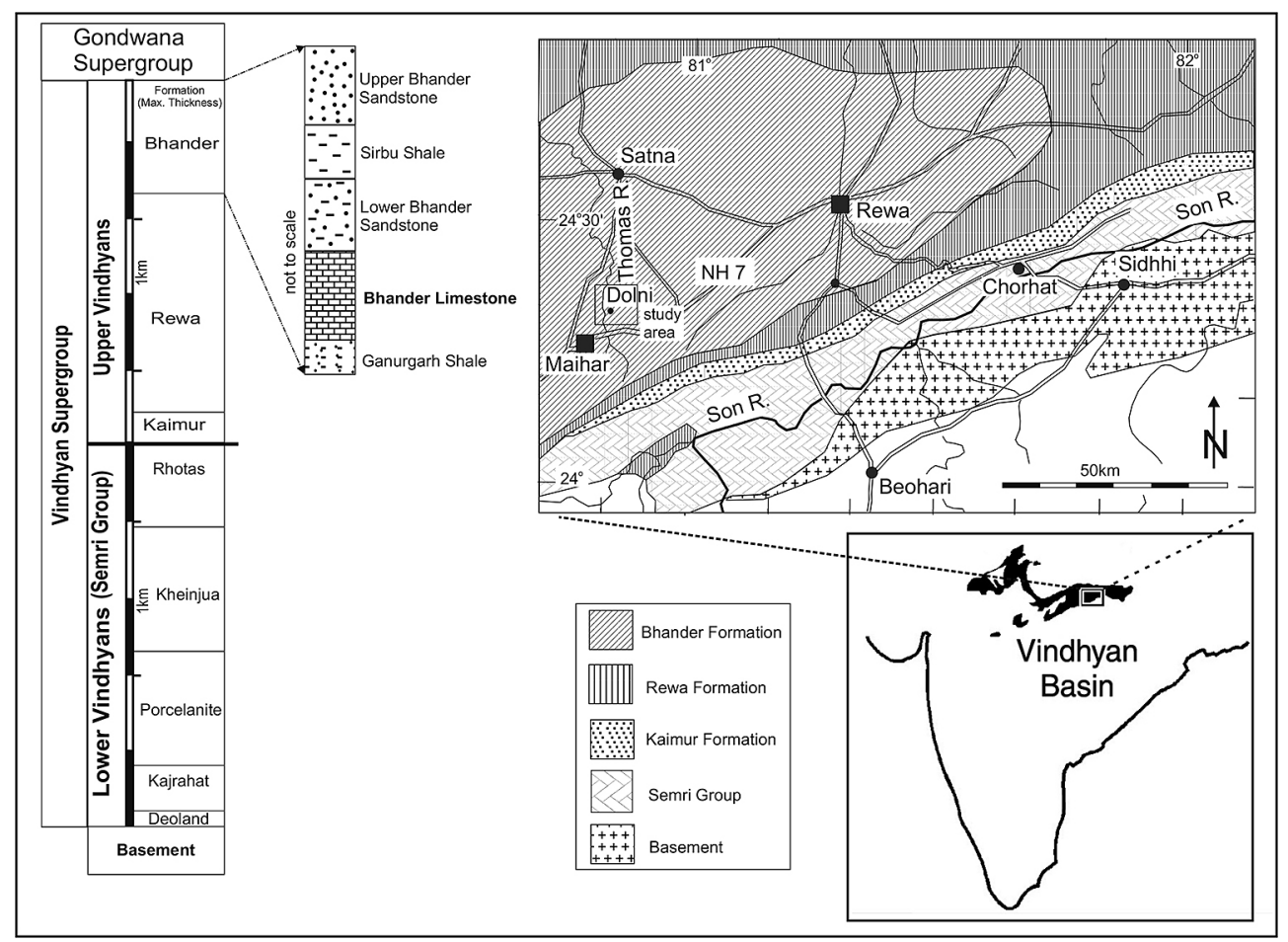

Fig. 1. Location map of the study area and stratigraphic context of the Bhander Limestone. 
Fig. 2. Relationship between the $\delta{ }^{13} \mathrm{C}$ and $\delta^{18} \mathrm{O}$ values for facies associations $\mathrm{A}$ and $B$ of the Bhander Limestone. Note the sharp positive shift of the $\delta{ }^{13} \mathrm{C}$ values at the transition from facies association A to B. Also note the poor correlation between the two ratios. Data from Sarkar et al. (1998).

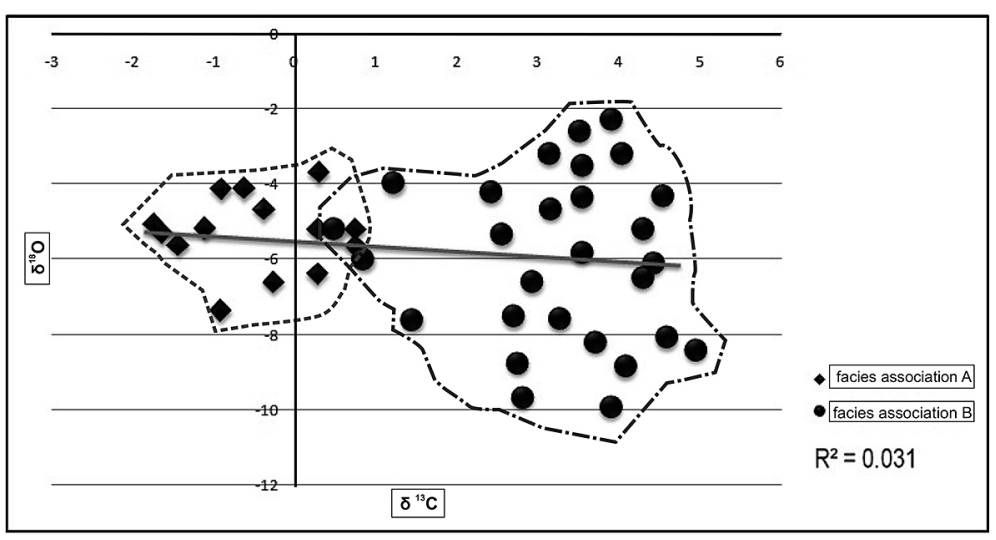

somewhat tentative (Sarkar et al., 1998; Chakraborty et al., 2002; Banerjee et al., 2006); some poorly correlated negative values of $\delta^{18} \mathrm{O}$ are evidence of diagenetic alteration (Fig.2). A marine environment is also likely because the underlying Rewa Formation contains clear tidal signatures (Bose \& Chakraborty, 1994).

The most convincing argument for a marine origin, at least for part of the formation (see below) is the nature of the glauconite that is present in the upper part of the succession under study. The glauconite occurs mostly as pellets; some K-feldspar grains show preferred glauconitisation along their margins and cleavage planes; the authigenic nature of this glauconite is undeniable. K-feldspar nuclei of some ooids also contain glauconite, and an early-diagenetic origin of this glauconite is also clear. We performed a chemical analysis of the glauconite on 23 glauconite grains from four samples. It appears that the $\mathrm{K}_{2} \mathrm{O}$ content of the glauconite pellets varies from 6.60 to $8.17 \%$ by weight. The total $\mathrm{Fe}_{2} \mathrm{O}_{3}$ content of the glauconite grains varies from 9.54 to $15.16 \%$ by weight. The $\mathrm{MgO}$ values range from 3.85 to $5.08 \%$ by weight. The glauconite samples with 6-8 wt. \% $\mathrm{K}_{2} \mathrm{O}$ are an evolved (highly mature) variety and those exceeding $8 \%$ are a very highly mature variety (Fig. 3; cf. Odin \& Matter, 1981; Amorosi, 1997; Banerjee et al., 2012a,b). The low $\mathrm{Fe}_{2} \mathrm{O}_{3}$ content is in good agreement with other Precambrian examples, which are interpreted as marine in origin (Dasgupta et al., 1990; Deb \& Fukuoka, 1998; Banerjee et al., 2008). The most decisive argument for a marine origin, however, is the high $\mathrm{MgO}$ content of these Bhander glauconites; ferromagnesian minerals are absent in the background rocks, so this high $\mathrm{MgO}$ content can have been derived only from the seawater. Banerjee et al. (2008) reported similar high $\mathrm{MgO}$ values from glauconites in the Palaeoproterozoic Khenjua and Deoland formations, which they also interpreted as marine in origin. This high $\mathrm{MgO}$ content of the glauconites of the Bhander Limestone

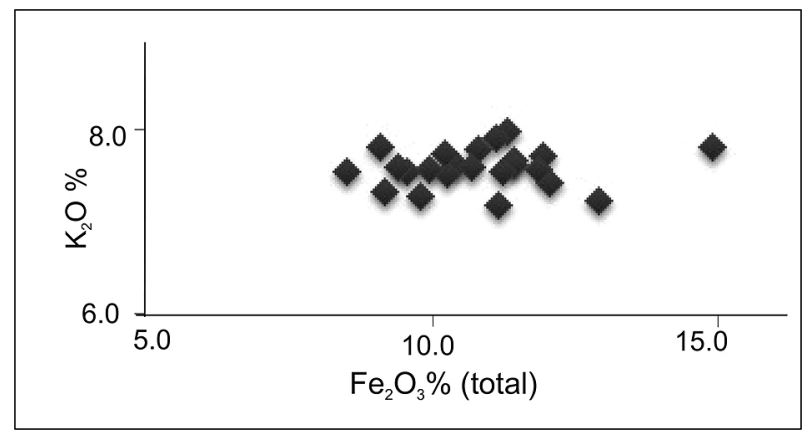

Fig. 3. $\mathrm{Fe}_{2} \mathrm{O}_{3} \mathrm{~K}_{2} \mathrm{O}$ plot for the glauconite pellets present preferably within the ripple-laminated facies B-3. Note that the $\mathrm{K}_{2} \mathrm{O}$ content amounts to $>6 \%$.

is in perfect agreement with the general sea-water enrichment in $\mathrm{MgO}$ in the Precambrian seas in comparison to their Phanerozoic counterparts (cf. Horita et al., 2007; Kump, 2008).

The occurrence of gypsum and barite in the Bhander Limestone (Kumar et al., 2005; Bose et al., 2012) and of gypsum and halite in the underlying Ganurgarh Shale and the overlying Lower Bhander Sandstone (Chakraborty et al., 1998; Kumar et al., 2005) indicate hypersaline conditions in restricted settings of carbonate deposition. Besides, the abundance of ooids supports this idea because in modern settings their preferred concentration is found along $25^{\circ} \mathrm{N}$ and S latitudes (Bathurst, 1975). The susceptibility of this carbonate sediment to deformation is large, particularly in the presence of evaporites (Orti et al., 2003).

\section{Facies analysis of the section under study}

The section of the Bhander Limestone under study consists of two main parts, with the three stacked seismites in between. The seismites themselves preserve little of their primary structures 
and are not considered for critical facies analysis, but lithologically they belong to the lower part. The successions below and above them have contrasting characters and are considered here as two different facies associations. The constituents of these two facies associations are described and interpreted below.

\subsection{Facies associations}

Two facies associations (Fig. 4a) are distinguished in the section under study; association $\mathrm{B}$ rests on top of association A. It is beyond the scope of the present contribution to deal with these associations and the contributing facies in detail. They are briefly described and interpreted here only in order to make the setting of the sediments with
SSDS more clear; details regarding characteristics and genetic interpretations are presented in Tables 1 and 2.

\subsubsection{Facies association $A$}

Facies association A, composed of intraclastic and muddy carbonate sediments comprises six facies: (A-1) an alternation of planar-bedded limestone and siliciclastic mudstone, (A-2) smallscale (wave) ripple-laminated limestone, (A-3) micro-scale convoluted limestone, (A-4) medium-scale hummocky cross-stratified limestone, (A-5) crinkly laminated limestone, and (A-6) carbonate breccia/ conglomerate. Only the first among these facies contains a significant amount of siliciclastic mud (Fig. 4b). It also shows polygonal desiccation cracks on bedding planes (Fig. 4c) consisting of v-shaped cracks in vertical section.

Table 1. Descriptions and interpretations of the depositional environment of individual facies in facies associations A.

\begin{tabular}{|c|c|c|}
\hline Facies & Description & Interpretation \\
\hline $\begin{array}{l}\text { A-1 An alternation of } \\
\text { planar-bedded lime- } \\
\text { stone and siliciclastic } \\
\text { mudstone }\end{array}$ & $\begin{array}{l}\text { Rhythmic alternations between mm scale planar } \\
\text { laminae of limestone and mudstone. Desiccation } \\
\text { cracks are common in occurrence. Encases thin con- } \\
\text { glomerates made up of round-edged tabular clasts } \\
\text { derived from the same facies. }\end{array}$ & $\begin{array}{l}\text { Microtidal depositional setting, } \\
\text { subjected to alternate emergence and } \\
\text { drowning. }\end{array}$ \\
\hline $\begin{array}{l}\text { A-2 Small- scale } \\
\text { (wave) ripple laminat- } \\
\text { ed limestone }\end{array}$ & $\begin{array}{l}\text { The facies is characterized by wave ripple laminae, } \\
\text { with preserved ripple forms on the bed surfaces. } \\
\text { The average height and spacing of these ripples } \\
\text { are } 5 \mathrm{~mm} \text { and } 10 \mathrm{~cm} \text { respectively. The ripples have } \\
\text { their crests straight or broadly sinuous and locally } \\
\text { bifurcated. }\end{array}$ & $\begin{array}{l}\text { Deposition took place in a lower flow } \\
\text { regime under wave influence. }\end{array}$ \\
\hline $\begin{array}{l}\text { A-3 Micro-scale convo- } \\
\text { luted limestone }\end{array}$ & $\begin{array}{l}\text { Stack of minute convolutes characterizes this facies, } \\
\text { highly restricted in lateral extent. Younger convo- } \\
\text { lutes incise into underlying older convolutes. }\end{array}$ & $\begin{array}{l}\text { Fluid escape and sedimentation con- } \\
\text { tinued simultaneously. Apparently } \\
\text { ripples migrated along the depositional } \\
\text { surface and comparatively greater } \\
\text { load within their troughs facilitated } \\
\text { displacement of fluid upward from } \\
\text { underneath. }\end{array}$ \\
\hline
\end{tabular}

A-4 Medium-scale Characterized by small-scale hummocky cross-strata Deposited by oscillatory flows. hummocky cross-strat- (amplitude and wave-length are $22 \mathrm{~cm}$ and $35 \mathrm{~cm}$ ified limestone respectively). The beds have bases very sharp and tops less sharp or even gradational. Locally their bases bear small gutter casts, prod and bounce marks. Ripples with straight or broadly sinuous and locally bifurcated crests are present on bed surfaces.

A-5 Crinkly laminated Crinkly laminated fine-grained limestone with occa- Microbialite, likely to be deposited in limestone sional clusters of micro-scale stromatolite columns.
A-6 Carbonate Brec-
This facies forms isolated lenticular bodies, en- cia/Conglomerate cased by intact laminated sediment. The constitu- ent clasts are internally planar laminated, tabular in shape and generally have beveled edges. The clasts generally lie bed-parallel. The beds generally have their bases planar, locally loaded and in some other cases erosional, concave upward. The rocks can be both clast-and matrix-supported.

a relatively calm and shallow energy domain.

Product of in-situ disruption and resedimentation. 
Facies A-1 with its mm-scale limestone/mud alternations resembles tidalites and thus strongly supports a marine environment (Sarkar et al., 1996). All facies point to deposition in a marginal marine environment, emerging locally and temporary (see Table 1). The abundant presence of desiccation cracks indicates frequent alternations of emergence and submergence, as in an intertidal-supratidal

Fig. 4. Facies of the Bhander Limestone.

a: Facies succession in several vertical logs, with their characteristics. Note the different character of the two facies associations (A, below the seismites; $\mathrm{B}$ above the seismites). The SSDS in the seismite interval are much larger than in the rest of the successions; $\mathbf{b}$ : Facies A-1, characterised by alternating planar laminae of limestone and mudstone; c: Polygonal desiccation cracks on the bedding plane. Note that clasts derived from the surrounding sediment fill the cracks; d: Breccia/conglomerate facies (A-6). Note that the clasts are tabular in shape, lie bed-parallel, show v-shaped cracks (solid arrows); some of them are bent (dotted arrows); e: Intense deformation and brecciation in the lower part of a bed (facies A-6). Note that the contact between zones with contrasting degrees of deformation is highly irregular and vague.
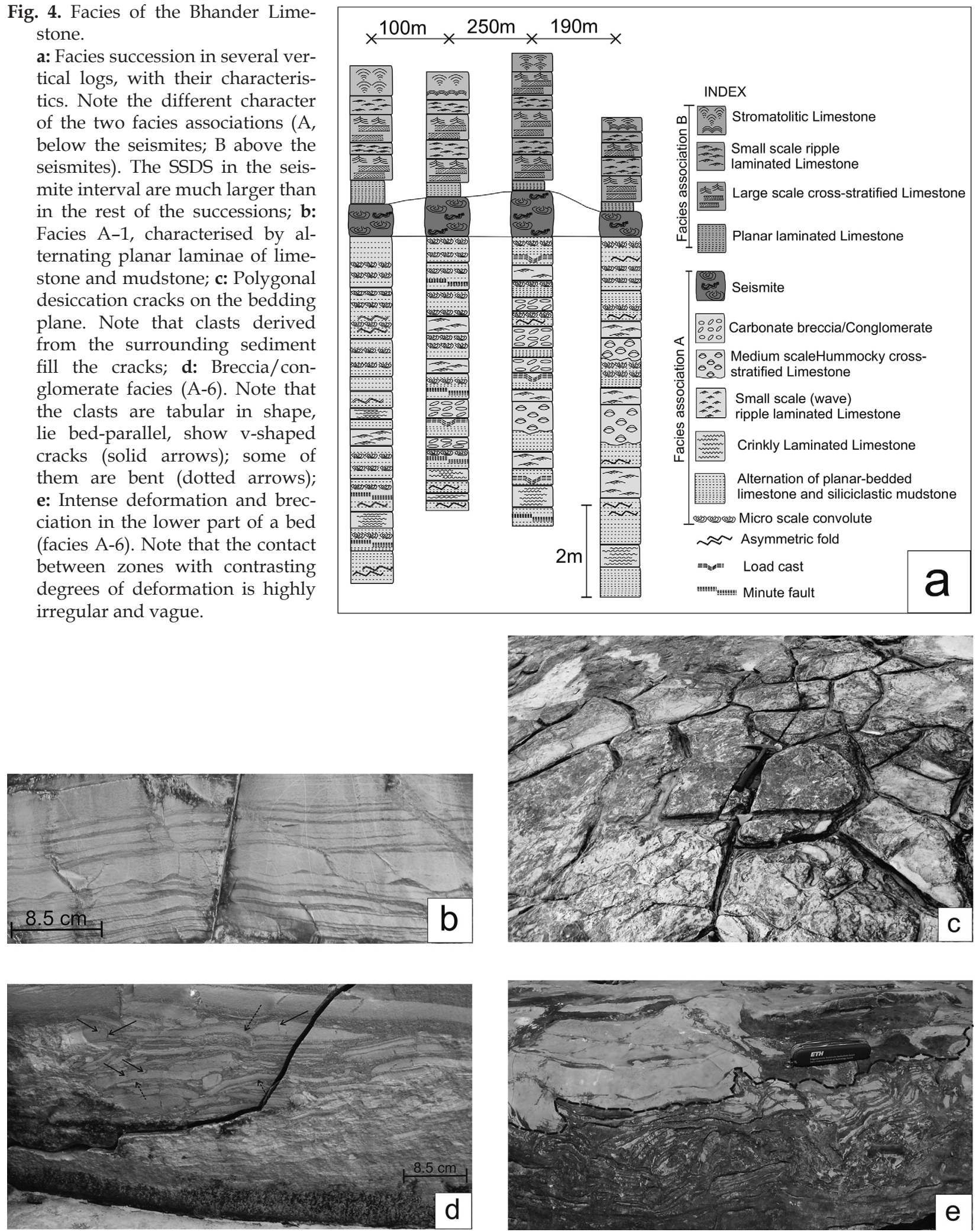
environment. Crystals of evaporites or their pseudomorphs in this association point to restricted circulation. The breccia/conglomerate facies (A6) is laterally discontinuous and was probably the result of local reworking of desiccated clasts (Fig. 4d). Some blocky breccia patches, however, must have formed otherwise, possibly through dissolution of evaporites (Fig. 4e). The local medium-scale hummocky cross-stratified facies (A-4) and the wave-rippled facies (A-3) point at occasional influence of oscillatory flows, possibly during events of strong wave activity. Taking all these data and the total absence of any bed form larger than smallscale ripples into account, it is likely that deposition of facies association A took place in a microtidal lagoon or a near-coast marine (inter- to supratidal) environment.

\subsubsection{Facies association $B$}

Facies association $B$ comprises four distinctive facies: (B-1) planar laminated limestone, (B-2) largescale cross-stratified limestone, (B-3) small-scale ripple-laminated limestone and (B-4) stromatolitic limestone (see details in Table 2). The first facies (B1 ) is present at one stratigraphic level only, confined to the base of association B. Facies B-2 and B-3 alternate with each other both laterally and vertically. Facies B-4 appears at the top of the succession under study as patches of variable dimensions, mostly of metre-scale.

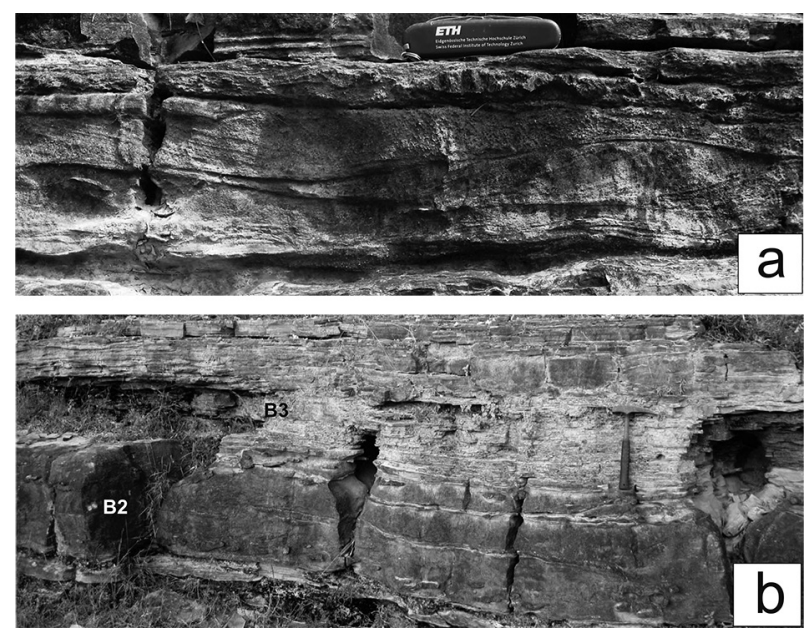

Fig. 5. Cross-stratified facies.

a: Wavy erosion surfaces and differently oriented sets of cross-strata within a single bed (facies B-2) interpreted as a bar; b: Small-scale ripple laminated interbar deposits (facies B-3) alternating with large-scale cross-stratified sediments (facies B-2).

The facies (B-2) with large-scale cross-strata, which are maximally some $30 \mathrm{~cm}$ thick and which show sometimes opposite directions, locally building up chevron structures, indicate substantial wave activity (Fig. 5a; De Raaf et al., 1977). Petrographically the entire facies is largely an oosparite. The lenticular bed geometry with flat bases and convex-upward tops are interpreted as wave-generated bars (Fig. 5b). The rippled facies (B-3) that al-

Table 2. Descriptions and interpretations of the depositional environment of the individual facies in facies association B.

\begin{tabular}{|c|c|c|}
\hline Facies & Description & Interpretation \\
\hline $\begin{array}{l}\text { B-1 Planar laminated } \\
\text { limestone }\end{array}$ & $\begin{array}{l}\text { Relatively fine- grained, well sorted and planar lam- } \\
\text { inated. This facies is non-repetitive in occurrence, } \\
\text { only at the base of the Association B. }\end{array}$ & $\begin{array}{l}\text { Appears to be product of sheet flow } \\
\text { under high energy depositional regime. }\end{array}$ \\
\hline $\begin{array}{l}\text { B-2 Large scale } \\
\text { cross-stratified lime- } \\
\text { stone }\end{array}$ & $\begin{array}{l}\text { Large scale cross stratified, coarse grained, oolitic, } \\
\text { having lenticular geometry, flat at base and con- } \\
\text { vex-upward on top. Locally, chevron cross-strata are } \\
\text { present. The average cross-set thickness } 30 \mathrm{~cm} \text {. }\end{array}$ & $\begin{array}{l}\text { Bar on marine shelf, originated under } \\
\text { wave agitation. }\end{array}$ \\
\hline $\begin{array}{l}\text { B-3 small scale ripple } \\
\text { laminated limestone }\end{array}$ & $\begin{array}{l}\text { Relatively finer grained multiple layers of cross-lam- } \\
\text { inae topped by ripple forms partially or entirely pre- } \\
\text { served. Lenticular in geometry having bases concave } \\
\text { upward without much of evidence for erosion. On } \\
\text { bedding plane exposures the ripple have straight or } \\
\text { broadly curved crests, locally bifurcating. The height } \\
\text { and spacing of the ripples, on average are } 5 \mathrm{~cm} \text { and } \\
25 \mathrm{~cm} \text { respectively. This facies occurs in lateral and } \\
\text { vertical alternations with the preceding facies. }\end{array}$ & Interbar \\
\hline $\begin{array}{l}\text { B-4 Stromatolitic } \\
\text { limestone }\end{array}$ & $\begin{array}{l}\text { Characterized by patchy occurrence of stromatolite } \\
\text { bodies encased by crinkled laminae. The strom- } \\
\text { atolites are both laterally attached and detached. } \\
\text { The latter ones are branching upward and have } \\
\text { their intercolumnar areas filled by stromatolite } \\
\text { fragments. }\end{array}$ & $\begin{array}{l}\text { Abundant microbial mat growth } \\
\text { within photic zone. Intercolumnar } \\
\text { areas, their filling with stromatolite } \\
\text { fragments and branching of columns } \\
\text { indicate an agitated depositional } \\
\text { environment. }\end{array}$ \\
\hline
\end{tabular}


ternates with this facies, and which consists mainly of oomicrite, is interpreted as an open-shelf interbar deposit (Fig. 5b). The stromatolite bioherms (facies B-4) indicate deposition within the photic zone, and the presence of stromatolite fragments between the stromatolite columns is consistent with a high depositional energy because of the wave activity.

\section{SSDS in facies association A, interpreted as non-seismogenic in nature}

Facies association A, which was interpreted above as representing lagoonal deposits, contains a wide variety of SSDS. They are present all over the facies association, but they are small in size with vertical heights that are most commonly at a millimetre scale, maximally up to a few centimetres. They may extend laterally for some distance but never at the scale of the entire exposure. Only some of them will be described and interpreted below, in order to provide more insight into their genesis and the conditions under which they were formed. SSDS with a distinctly non-seismic origin, such as desiccation cracks are considered here out of scope.

\subsection{Description of some SSDS}

Convolute folds occur at numerous levels within facies association A. Locally they form a single level of convolutions with a height of centimetre scale (Fig. 6a). More commonly they are smaller (mmscale) and present in packages, with younger convolute structures truncating older ones (Fig. 6b). In both cases their peaks are relatively narrow, whereas their troughs are relatively wide. Some elongated pillow-like structures have elongated axes (unlike the convolute structures) and their axial planes are inclined at low angles with the bedding planes (Fig. 6c). Minor asymmetric folds, solitary or in packages (Figs. 7a, b), also occur at several levels (Fig. 4a); they have some resemblance with ripples, but unlike ripples these folds have narrow troughs, and their crests may be rounded.

Small-scale folding characterises some beds in which the deformation is distinctly more intense or more complex in their basal parts. The folds have asymmetrical limbs, the steeper ones all being inclined into the same direction (Fig. 7c). The surfaces between the less and the more deformed parts within a layer or a set of layers are planar or slightly curved.

In situ brecciation locally characterises the lower parts of some other beds; the boundaries between
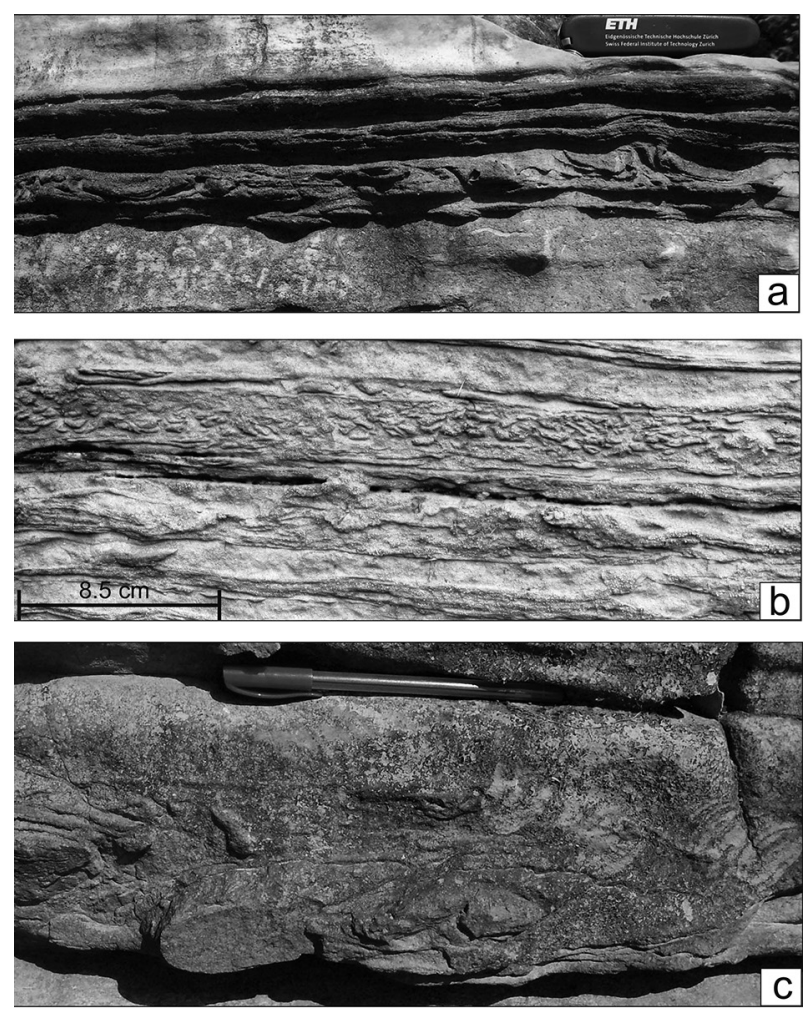

Fig. 6. Convolutions in facies association A. a: Small-scale convolutions limited to one layer (facies A-3); b: Layer (facies A-3) with mm-scale convolutions. The higher (younger) convolutions deform the lower (older) ones; c: Pillow-like slump folds (facies A-3) with elongated axes (bottom, centre); the axial planes are at a small angle with the bedding plane. Length of pen $15 \mathrm{~cm}$.

the brecciated and non-brecciated parts are highly irregular (Fig. 4e). Within a well-laminated layer, the downward bending of the upper laminae creates a U- to V-shaped structure, with deformation at its brecciated base (Fig. 8). Above the deformed layer, the topmost part of the bed is completely homogenised (Fig. 8), which makes it unlikely that the downward bending of the laminae below is the result of loading.

Tilted segments characterise certain layers, the tilting being in the same or in opposite directions within a bed. The internal laminae within the undeformed segments of these layers as well as in the tilted segments are intact. Despite rotation of the fragments, all segments of the layer touch each other (Fig. 9). There are, however, also many breccia and conglomerate beds of different dimensions, the constituent clasts of which float within a finer-grained matrix. The clasts of these breccias and conglomerates have in some cases sharp edges and are in other cases somewhat rounded. The clasts are generally tabular in shape, elongated, internally laminated and positioned bed-parallel. Some clasts 

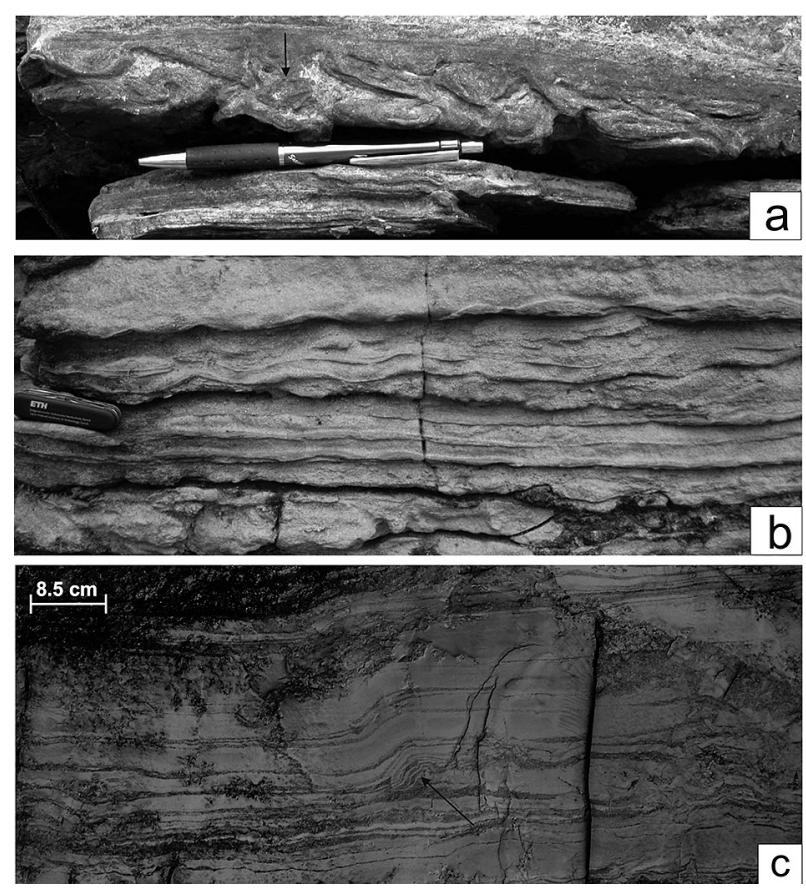

Fig. 7. Small-scale folds in facies association A. a: A train of tight small-scale shear folds that were locally fragmented (arrow); b: Successive layers with small-scale shear folds; c: More intricate folding in the lower part of a bed (facies A-1). Note that the contact between the zones with different degrees of deformation is well defined. Length of pen $15 \mathrm{~cm}$.

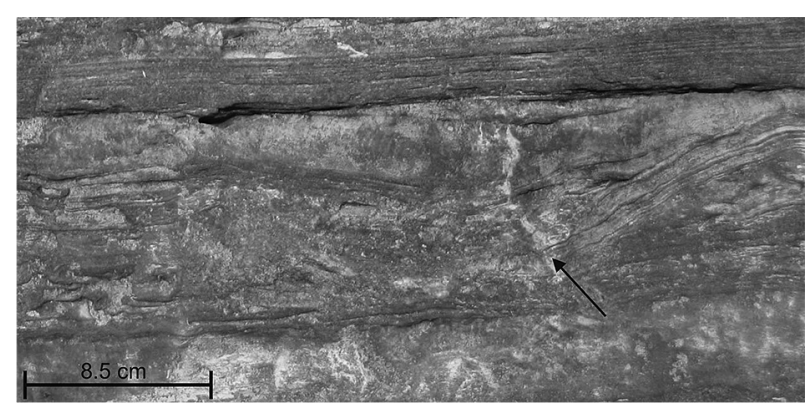

Fig. 8. V-shaped collapse structure in a slightly cemented bed (facies A-1). Note the filling of the depression created on top of the bed by homogenised sediment. Also note the fragmentation of the laminated layer in the central part of the ' $\mathrm{V}$ '. The homogenised sediment at the top is possibly due to fluidisation that took place as a result of the collapse.

are slightly bent and some other clasts show (parts of) desiccation cracks (Fig. 4d). The breccia layers are wedge-shaped and laterally pinch out, while undeformed laminae wrap them all around. Compositionally the clasts are identical to the surrounding sediment (Fig. 10 a, b) (see also Van Loon, 2014b, this issue); in some cases the breccia layers can be traced laterally until they gradually or abruptly pass into their parent bodies (Fig. 10a ). Some other finer-grained, granular, clastic carbonate beds have

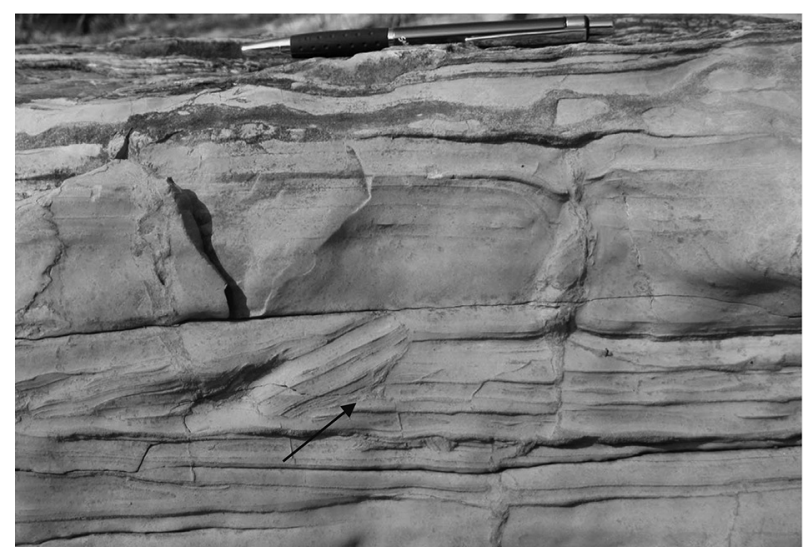

Fig. 9. Tilting at different angles (but in the same direction) of fragments of a locally broken-up layer. Note that the internal laminae are intact both within the fragments and the intact part of the layer (facies A-1). Length of pen $15 \mathrm{~cm}$.

locally erosional bases (Fig. 10c, d). Some other layers have load-casted bases (Fig. 11).

Laminae bent around concretions are a fairly common feature within facies association A. In some cases, the laminae both below and above the concretion are enveloping it. The concretions were originally ellipsoidal or spherical in shape (cf. Coleman \& Raiswell, 1995) but they have disappeared due to dissolution. The dissolution created empty spaces that are now partially or entirely filled by calcic spar (Fig. 12a). In other - much rarer - cases, the concretions have flat bases and convex-upward tops; the draping laminae are present only around the top of these concretions and their internal laminae tend to bend downward at the edges. These concretions did not suffer dissolution like the type mentioned above (Fig. 12b).

Finally, mm-scale faults are common in many layers, especially within the fragments floating within massive limestone beds (Fig. 13).

\subsection{Interpretation of the SSDS}

Regarding the genesis of the above SSDS, upward escape of water/sediment mixtures must be considered as an important process involved in the formation of convolute structures (cf. Sanders, 1960; Ghosh \& Lahiri, 1990; Owen, 1996; Üner, 2014, this issue; Valente et al., 2014, this issue); such deformations developed metadepositionally, after deposition but before accumulation of the next layer (Nagtegaal, 1963; Van Loon, 2009). However, where younger convolutions affect older ones, deformation and deposition must have taken place almost simultaneously. One of the likely sequenc- 


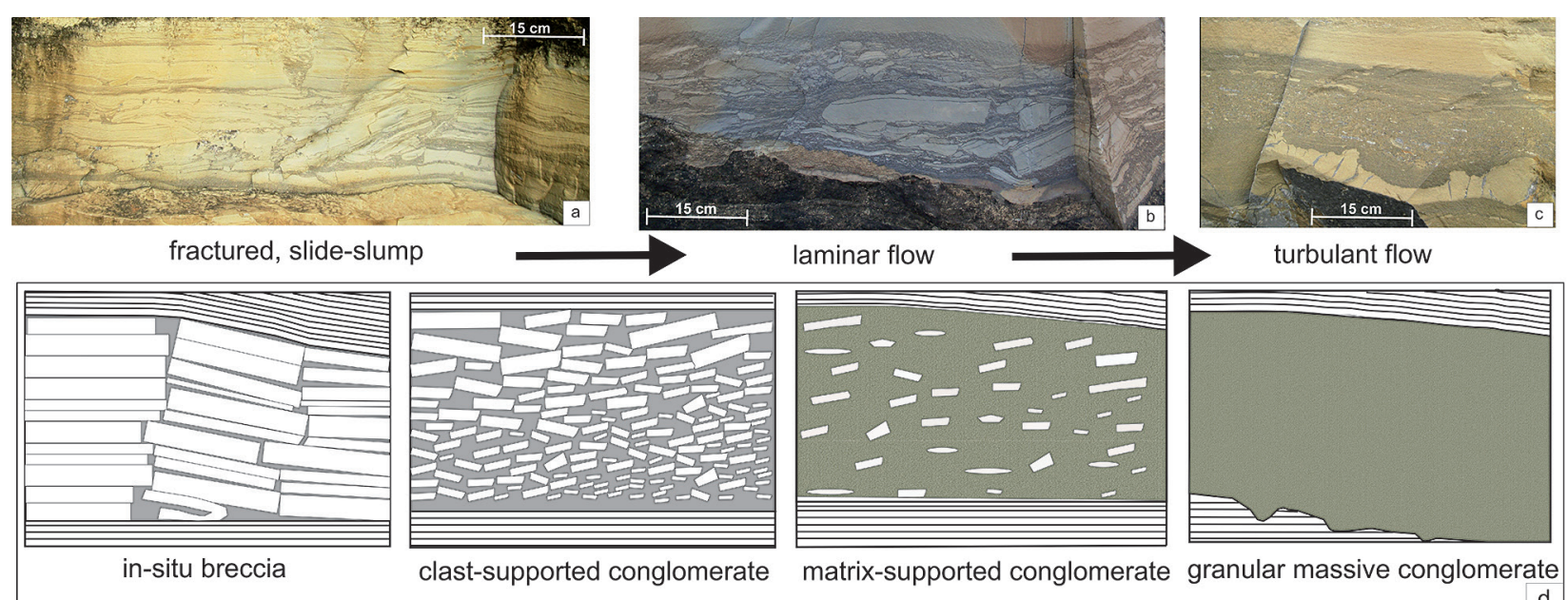

Fig. 10. Presumed model for the development of breccias/conglomerates (facies A-6) after in-situ brecciation accompanied by minimal slide and slump in successive stages, showing (bottom of the figure) the changes in rock fabric depicted in the top row of the figure.

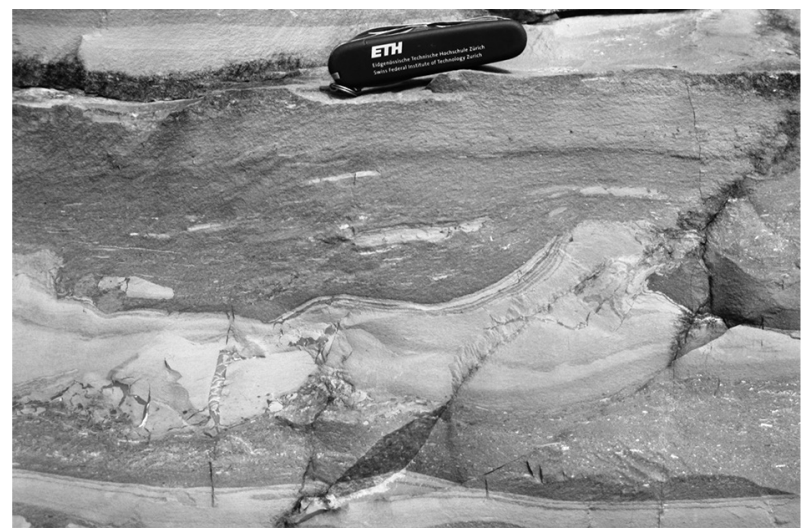

Fig. 11. Granular clastic carbonate bed (facies A-6) with an irregular loadcasts at its base. Note the large clasts in the bottom part of the loadcast.

es of events involved is the truncation of peaks of already existing convolutions by wave or current ripples and sagging of the ripple troughs because of accumulation of (relatively heavy) sand in them, resulting in unstable density gradients so that loadcasting took place (Van Loon, 2009, and references therein; see also He et al., 2014, this issue). Obviously, simultaneous fluidisation and liquefaction was required (cf. Lowe, 1975; Berra \& Felletti, 2011).

Slumping is the likely process involved in the genesis of the pillow-like structures shown in Figure $6 c$; a strong overriding-induced shear is required to explain the tight character of such folds as well as their almost bed-parallel axial planes (see also Perucca et al., 2014, this issue). The rows of minor asymmetric folds in Figure $7 \mathrm{~b}$ also record overriding shear induced by density flows or sliding masses of sediment in the direction of the steeper limbs of the folds; sliding seems the more
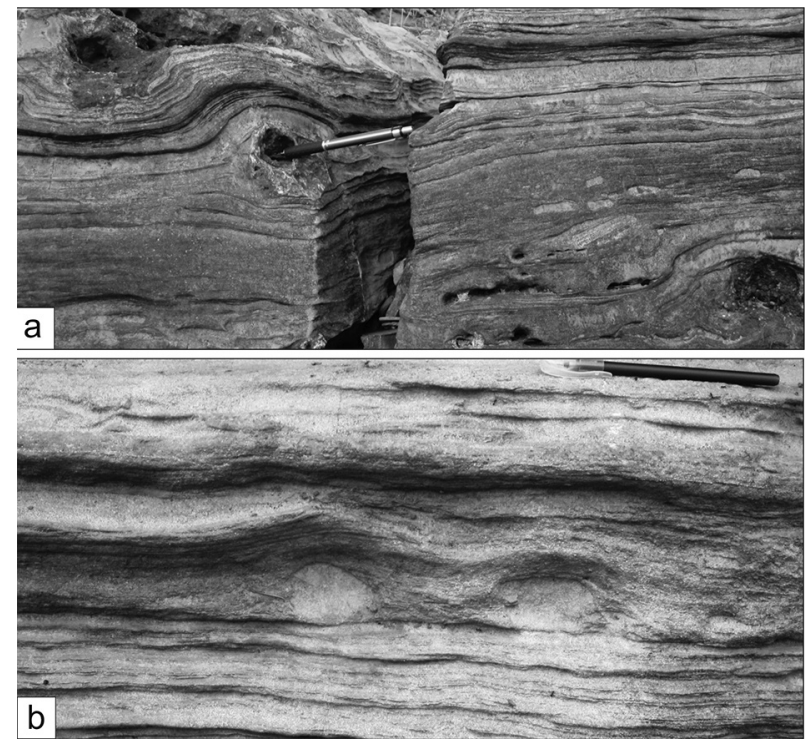

Fig. 12. Deformed lamination around concretions (facies A-1).

a: Laminae bent around both the top and below ellipsoidal to spheroidal concretions. Note that the concretions became dissolved and later partially filled by calcite spar; $\mathbf{b}$ : Laminae bent only around the tops of concretions, whereas the lamination below the concretions is undisturbed. Note that the internal laminae of the concretions are bent downwards at the edges. Also note that these concretions did not suffer dissolution as in Figure 12a. Length of pen $14 \mathrm{~cm}$.

likely of these two processes, considering the commonly low energy level and the slow sedimentation in the depositional environment. The smooth curvilinear plane between the less deformed upper part and the more deformed basal part of the bed in Figure 7c are genetically related features. Most likely this feature resulted from differential 


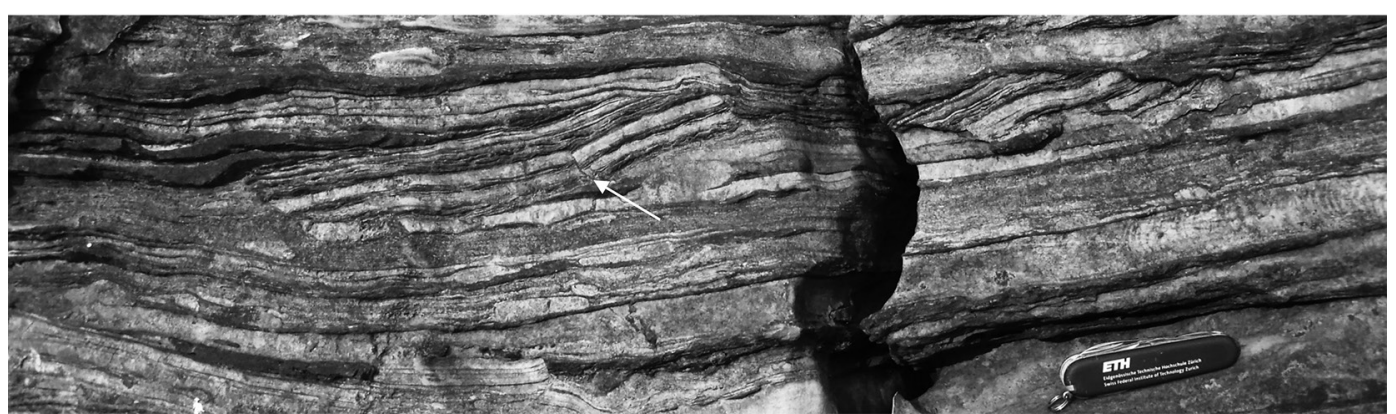

Fig. 13. Mm-scale faults within bed-fragments floating within a massive matrix (facies A-6).

movement between the two parts of the bed. The unidirectional asymmetry of the folds in both the parts suggests a unidirectional movement, probably as a result of slight downward movement en masse on a slightly inclined water-saturated slope (Fig. 7c; Cook \& Mullions, 1983).

The irregular contact between the lower brecciated and the upper non-brecciated parts of a single bed such as that shown in Figure 4e tells a different story. The matching boundaries between adjacent clasts strongly suggest in-situ brecciation, possibly caused by dissolution of evaporites. Another possibly dissolution-related deformational process is foundering, which is clearly visible as down-buckling of the upper laminae of a bed and rupture at the base of v-shaped collapse structures (Fig. 8). The homogenised sediment in the topmost part of the same bed is most likely due to upward escape of an overpressurised water/sediment mixture through a crack developed during the collapse of very slightly cemented sediment. Apparently dissolution took place under the topmost sedimentary material.

The layers with fragmented parts must have undergone early cementation, so that the primary laminae remained intact within the clasts and the clasts acquired sharp edges. Where rotated and intact segments of a bed are still in touch with each other, shortening of the original sediment layer must have occurred and it must be deduced that the rate of sliding for the individual segments was not the same all the time, and in the case illustrated in Figure 9 it must have slowed down in the direction of movement. The bending shown by some clasts indicates that their lithification was not yet complete before displacement, but that they must have reached a considerable degree of consolidation.

The matrix-supported breccias and conglomerates have certainly undergone transportation, but to variable degrees. The beds that can be traced laterally until they pass into undisturbed parent beds presumably suffered only minor dislocations. Detached clasts floating in a finer-grained matrix indi- cate, in contrast, longer transport in a viscous flow. The formation of parallel fractures and consequently the fragmentation of the original sediment into clasts is evident in Figure 10a; the combination with Figure $10 \mathrm{~b}$ illustrates how the clasts were carried away from their parent bodies. The bed-parallel orientation of the clasts in the conglomerates results from the laminar nature of the flows (Enos, 1977), which must have had a very high viscosity considering the sometime delicate and fragile shapes of the clasts.

In contrast, the scoured bases of the finest carbonate clastic beds reflect turbulence within the sediment/water mixture, at least immediately prior to deposition. The four kinds of reworked carbonate clastic beds can then find their place in a synthetic model for downcurrent flow evolution; the flow transformation from laminar to turbulent might have occurred due to a steepening slope of the depositional substratum or reduction in sediment concentration within the flow (Fig. 10d; Fisher, 1981).

Both types of concretions described above appear to have formed early, but the concretion hardened or got cemented earlier when surrounding laminae surrounded it both below and above than when the laminae wrap around its top only. The dissolution of all concretions with deformed laminae at both sides suggests that these concretions originally consisted of evaporites. Apparently a high ion concentration led to relatively rapid cementation. The second type of concretions were clearly formed after cementation of the substratum; downturning of their internal laminae at the edges indicates that their growth had been slow and continued while the overburden started to build up a pressure (cf. Seilacher, 2001). The abundant occurrence of microfaults within the otherwise undisturbed beds as well as within authigenic clasts clearly reflects a condition that was favourable for early cementation, as is to be expected under the influence of meteoric water in a shelf lagoon where facies association A was deposited. 


\section{SSDS interpreted as seismogenic}

A laterally continuous stratigraphic interval with a thickness of, on average, $60 \mathrm{~cm}$ with abundant SSDS can be traced all over the section under study between the facies associations A and B (Fig. 4a). This interval is composed of three stacked layers; at the base of each of them a row of small ripple-like asymmetric shear folds occurs (Fig. 14). The average thickness of the three individual layers is some $20 \mathrm{~cm}$. As will be discussed below, these three stacked layers are interpreted as seismites.

\subsection{Description of the SSDS in the three stacked layers}

The most common type of SSDS in the three layers in between the facies associations A and B are convolutions, widely varying in shape. Single and multiple types are present, with one or more lobes, symmetrical or asymmetrical (Fig. 15). In comparison to their counterparts in facies association A, all these convolutions are distinctly larger, with an average height of $13 \mathrm{~cm}$ and an average width of $28 \mathrm{~cm}$. Further, there are contorted laminae and micro-faults.
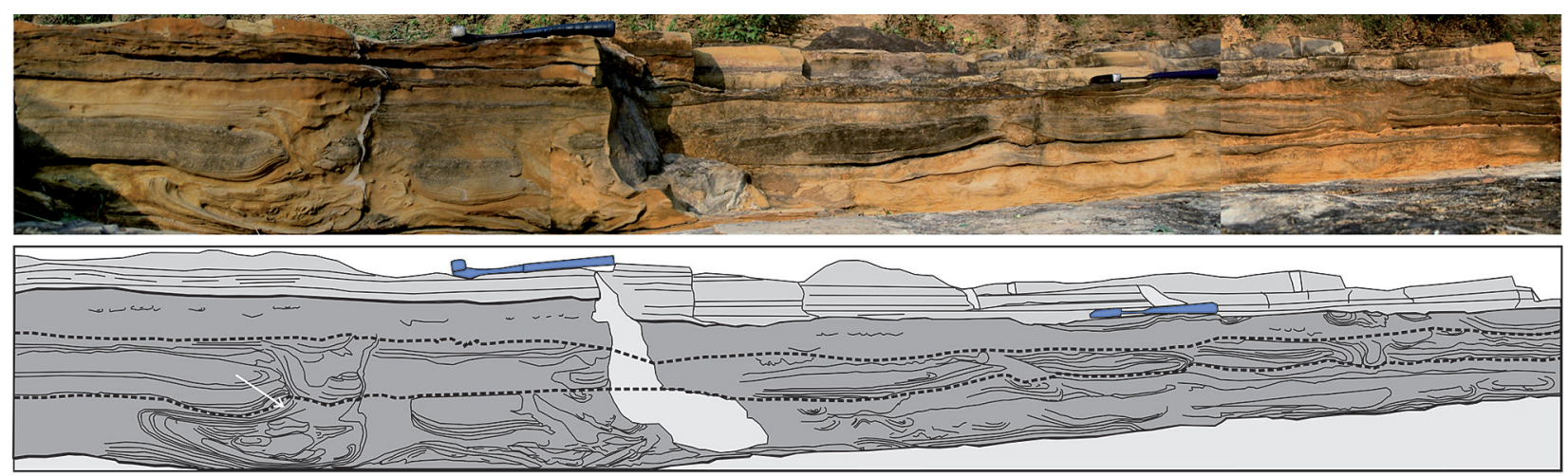

Fig. 14. The three vertically amalgamated seismites at the boundary between facies associations A and B. The individual seismites are separated from each other by detachment planes locally represented by shear folds. Note the droplets (arrowed). The size of the SSDS is largest in the lowermost seismite and smallest in the uppermost seismite, suggesting a relatively strong earthquakes and aftershocks of decreasing intensity.

Fig. 15. Convolutions in the seismites. a: Single simple lobe. b: Complex lobe. c: Symmetrical lobe. d: Asymmetrical lobe. Length of pen $14 \mathrm{~cm}$.
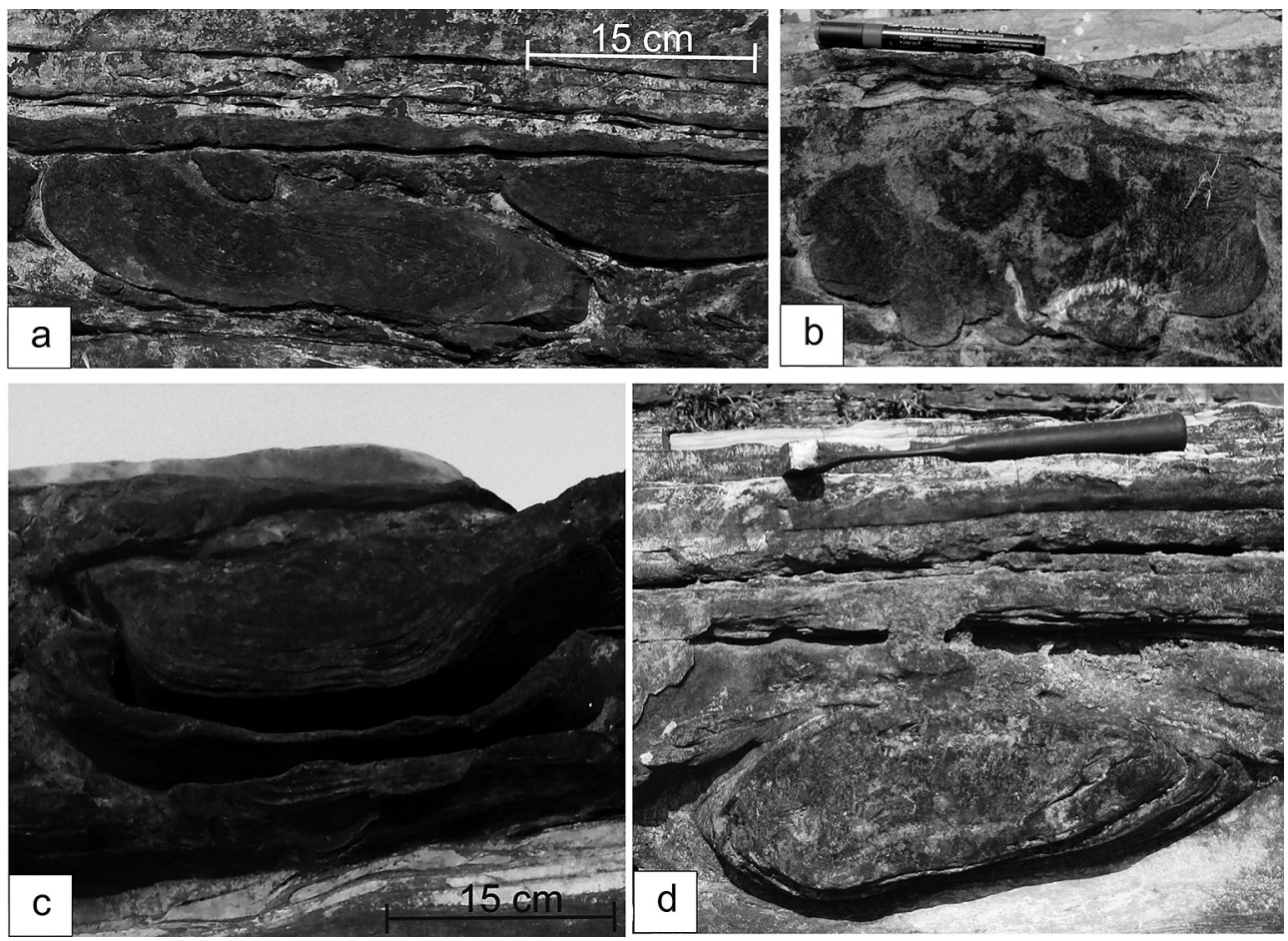
In addition, there are droplets in the same carbonate sediment that are constricted at the top and wider at the bottom; occasionally they pass downwards through narrow gaps between the closely spaced convolutions (Fig. 14). They are comparable with the convolutions in height, but narrower.

\subsection{Interpretation}

The droplets constricted between adjacent convolutes and rapidly expanding beneath them where more space was available (Fig. 14), clearly indicate that they succeeded the convolutes. The coexistence of convolutes and droplets in the same layer seems to rule out a significant gap in time between the two deformation processes; fluidisation and liquefaction must have taken place almost simultaneously. High-frequency seiches, as those that may arise during an earthquake event could be a suitable explanation for the simultaneous deformation and sedimentation, fluidisation and liquefaction, though not unequivocally.

A similar conclusion can be drawn with respect to the multilobe convolutions. Once dewatered, sediments are not likely to undergo ductile deformation unless successive pulses bring forth new masses of pore water. Ghosh \& Lahiri (1990) experimentally generated similar structures from a density-stratified mass by repeated shocks. The vertical stacking of the convolutions, with younger ones affecting the older ones in the seismite level, clearly demonstrates, as argued above, that deformation and sedimentation took place almost simultaneously. Mainly upward or downward movement of material is indicated by these convolutions and droplets, but some limited lateral sliding also took place, as indicated by the asymmetric convolutions and the minor shear folds at the base of each of the three seismites.

The flat or slightly undulating bases of these shear folds are the planes of detachment across which the deformational force could not propagate downwards; the difference in the scale of deformation below and above these detachment planes is always substantial (Fig. 14). The vertical amalgamation of the three successive levels of deformation also indicates recurrence of the deformation process, perhaps after several days, as is common in the case of earthquake aftershocks.

\subsection{Arguments in favour of seismites}

The deformation processes and their successive occurrences as described in Sections 5.1 and
5.2 for the SSDS in the three deformed layers at the boundary between facies associations A and B are entirely consistent with what may be expected from an earthquake (see Moretti \& Van Loon, 2014). Not only are the SSDS significantly larger than the SSDS that are abundantly present throughout facies association $\mathrm{A}$, but they also constitute a level that is traceable all over the section under study; in contrast, hardly any SSDS are found in facies association $\mathrm{B}$, and, where present, the latter are much smaller, indicating a less intense deformation process. It must thus be deduced that the level with the three strongly deformed layers developed during an event that affected the sediments over an extensive area, and that the deformation processes involved were much stronger than before and after this event, and that the event included (at least) three deformation phases, shortly after one another (cf. Van Loon \& Pisarska-Jamroży, 2014), in the form of aftershocks of an earthquake.

The vertical transition from facies association A to B clearly documents a rapid transgression of the sea, which points at either an exceptionally rapid sea-level rise (for which feature no arguments have been found elsewhere) or an uncommonly rapid basin subsidence. This subsidence led to a sudden transition from a low-energy marginal marine or lagoonal environment (facies association A) to an open, agitated shelf environment (facies association B). This transition is reflected not only by the large-scale cross-strata that occur only in facies association B, but also by the ripple heights, which also sharply increased from the onset of the transgression on. The facies that immediately overlies the three strongly deformed layers is the deepest among all in the two facies associations

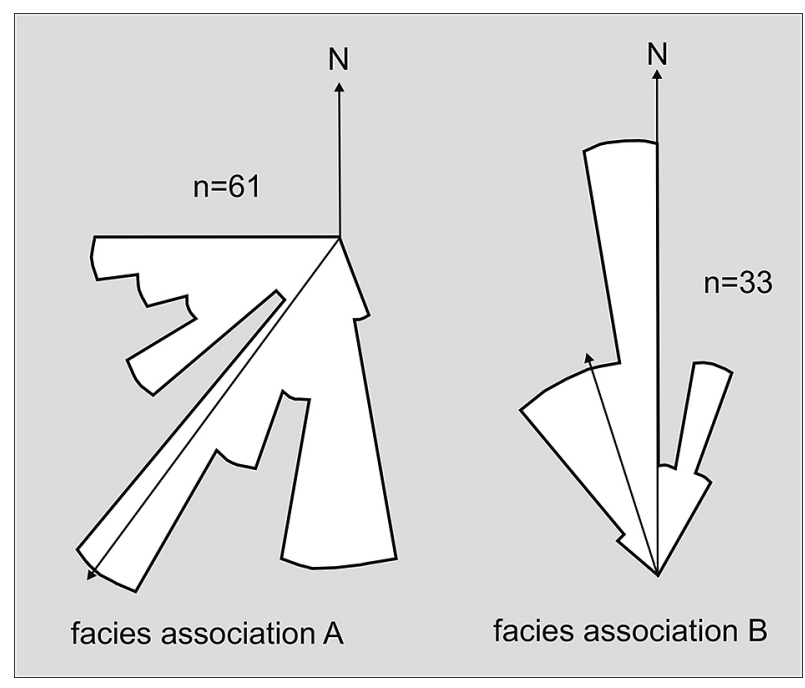

Fig. 16. Palaeocurrent directions in the two facies associations as deduced from current ripples. 
(Chakraborty, 1996) and implies that the relative sea level rose very fast to the maximum. The combination of the regional occurrence of these SSDS with the evidence of a sudden sharp rise in sea level can be explained satisfactorily only by tectonic activity that started very intensely (with earthquakes that deformed the layers at the sedimentary surface) and that led to rapid basin subsidence. It should be noted in this context that the supply of sediment remained so high that further subsidence of the basin did not result in further deepening, but rather in some shallowing because the sedimentation rate was higher than the subsidence rate.

A sudden change in the palaeogeographical configuration at the boundary between facies associations A and B is obvious also from the palaeocurrent directions. The ripples indicate strongly differently directed palaeocurrents in facies associations A and B (Fig. 16). Important other parameters that changed drastically when the waves passed the boundary between facies associations $\mathrm{A}$ and $\mathrm{B}$ are the $\delta^{13} \mathrm{C}$ values of Sarkar et al. (1998) when sorted out for the two associations (Fig. 2). The sharp positive shift across the seismite interval is one more argument supporting a rapid increase in water depth.

\section{Conclusions}

The following conclusions can be drawn from the study of the Proterozoic Bhander Limestone in a section of some $750 \mathrm{~m}$ long.

(1) Two facies associations (A and B) can be distinguished, separated by three stacked layers that form a relatively thin succession full of relatively large soft-sediment deformation structures (SSDS).

(2) Facies association A represents a microtidal hypersaline marginal marine environment/lagoon and contains numerous small-scale SSDS that can all be explained by processes related to the abundant presence of evaporites many of which underwent dissolution causing collapse of sedimentary layers. The sediments were also susceptible to deformation processes due to a relatively low viscosity which resulted from the presence of evaporites.

(3) Facies association B represents an open-marine shelf environment. SSDS are hardly present (no evaporites were present). The marine character is obvious from the presence and the chemical composition of authigenic glauconite at some levels of the facies association.

(4) The sudden change from a very shallow marginal marine/lagoonal environment to an open-marine setting indicates a sudden and quick subsidence of the basin (which indicates tectonic activity), which took place immediately after the deposition of the 3 deformed layers. The environmental change resulting from sudden deepening of the basin is supported by a distinct upward positive shift of the $\delta^{13} \mathrm{C}$ values. The changed conditions are also clear from the change in palaeocurrent directions.

(5) The three stacked layers at the boundary between the two facies associations are deformed over their entire lateral extent. Fluidisation and liquefaction played a major role in their genesis, suggesting exposure to a shock wave. In combination with the size of the deformations, which are much larger than those elsewhere in the succession, and in combination with the sudden tectonic activity, these three layers are interpreted as seismites. As they are present immediately on top of each other, they may reflect an earthquake and aftershocks.

(6) The succession is one of the few where seismically induced SSDS co-exist with non-seismic SSDS. The fact that these two genetic types differ fundamentally in nature, size and intensity, may help distinguish between them in future research.

(7) The evidence of seismicity in a carbonate formation deposited in an intracratonic sag basin makes clear that even the tectonically most quiet areas can be affected by earthquakes.

\section{Acknowledgements}

All authors express their gratitude to the respective institutions for infrastructural facilities. S.S. and P.K.B. acknowledge field grants from the DST, Government of India.

\section{References}

Akhtar, K., 1996. Facies, sedimentation processes and environments in the Proterozoic Vindhyan Basin, India. Memoir of Geological Society of India 36, 127-136.

Amorosi, A., 1997. Detecting compositional, spatial, and temporal attributes of glaucony: a tool for provenance research. Sedimentary Geology 109, 135-153.

Banerjee, S., Bhattacharya, S.K. \& Sarkar, S., 2006. Carbon and oxygen isotope compositions of the carbonate facies in the Vindhyan Supergroup, central India. Journal of Earth Systems Science 115, 113-134.

Banerjee, S., Jeevankumar, S. \& Eriksson, P.G., 2008. Mg-rich illite in marine transgressive and highstand system tracts: examples from the Palaeoproterozoic Semri Group, central India. Precambrian Research 162, 212-226.

Banerjee, S., Chattoraj, S.L., Saraswati, P.K., Dasgupta, S. \& Sarkar, U., 2012a. Substrate control on formation and maturation of glauconites in the Middle Eocene 
Harudi Formation, western Kutch, India. Marine and Petroleum Geology 30, 144-160.

Banerjee, S., Chattoraj, S.L., Saraswati, P.K., Dasgupta, S., Sarkar, U. \& Bumby, A., 2012b. The origin and maturation of lagoonal glauconites: a case study from the Oligocene Maniyara Fort Formation, western Kutch, India. Geological Journal, doi: 10.1002/gj.1345.

Bathurst, R.G.C., 1975. Carbonate sediments and their diagenesis. Developments in Sedimentology, Vol. 12. Elsevier (Amsterdam) 439 pp.

Berra, F., \& Felletti, F., 2011. Syndepositional tectonics recorded by soft-sediment deformation and liquefactionstructures (continental Lower Permian sediments, Southern Alps, Northern Italy): Stratigraphic significance. Sedimentary Geology 235, 249-263.

Bose, P.K. \& Chakraborty, P.P., 1994. Marine to fluvial transition: Proterozoic Upper Rewa Sandstone, Maihar, India. Sedimentary Geology 89, 285-302.

Bose, P.K., Banerjee, S., \& Sarkar, S., 1997. Slope-controlled seismic deformation and tectonic framework of deposition: Koldaha Shale, India. Tectonophysics 269, 151-169.

Bose, P.K., Sarkar, S., Chakraborty, S. \& Banerjee, S., 2001. Overview of the Meso- to Neoproterozoic evolution of the Vindhyan basin, central India. Sedimentary Geology 141, 395-419.

Bose, P.K., Eriksson, P.G., Sarkar, S., Wright, D., Samanta, P., Mukhopadhyay, S., Mandal, S., Banerjee, S. \& Altermann, W., 2012. Sedimentation patterns during the Precambrian: a unique record. Marine and Petroleum Geology 33, 34-68.

Campbell, K.A., Nesbitt, E.A. \& Bourgeois, J., 2006. Signatures of storms, oceanic floods and forearc tectonism in marine shelf strata of the Quinault Formation (Pliocene), Washington, USA. Sedimentology 53, 945-969.

Chakraborty, P.P., 1996. Facies and sequence development in some late Proterozoic Formations in Son valley, India with some clues for basin evolution. Unpublished Ph.D. thesis Jadavpur University (Calcutta) 104 pp.

Chakraborty, P.P., 2011. Slides, soft-sediment deformations, and mass flows from Proterozoic Lakheri Limestone Formation, Vindhyan Supergroup, central India, and their implications towards basin tectonics. Facies 57, 331-349.

Chakraborty, P.P., Sarkar, S. \& Bose, P.K., 1998. A viewpoint on intracratonic chenier evolution: clue from a reappraisal of the Proterozoic Ganurgarh Shale, central India. [In:] B.S. Palliwal (Ed.): The Indian Precambrians. Scientific Publishers (Jodhpur), 61-72.

Chakraborty, P.P., Sarkar, A., Bhattacharya, S.K. \& Sanyal, P., 2002. Isotopic and sedimentological clues to productivity change in Late Riphean Sea: a case study from two intracratonic basins of India. Proceedings of the Indian Academy of Sciences (Earth and Planetary Sciences) 111, 379-390.

Chanda, S.K. \& Bhattacharya, A., 1982. Vindhyan sedimentation and paleogeography: Post-Auden developments. [In:] K.S. Valdiya, S.B. Bhatia \& V.K. Gaur (Eds.): Geology of Vindyanchal. Hindustan Publ. Corporation, Delhi, 88-101.
Chen, J., Chough, S.K., Chun, S.S. \& Han, Z., 2009. Limestone pseudoconglomerates in the Late Cambrian Gushan and Chaomidian Formations (Shandong Province, China): soft-sediment deformation induced by storm-wave loading. Sedimentology 56, 1174-1195.

Coleman, M.L. \& Raiswell, R., 1995. Source of carbonate and origin of zonation in pyritiferous carbonate concretions: evaluation of a dynamic model. American Journal of Science 295, 282-308.

Cook, H.E. \& Mullins, H.T., 1983. Basin margin environment. American Association of Petroleum Geologists Memoir 33, 540-617.

Dasgupta, S., Chaudhuri, A.K. \& Fukuoka, M., 1990. Compositional characteristics of glauconitic alterations of K-feldspar from India and their implications. Journal of Sedimentary Petrology 60, 277-281.

Davies, S.J. \& Gibling, M.R., 2003. Architecture of coastal and alluvial deposits in an extensional basin: the Carboniferous Joggins Formation of eastern Canada. Sedimentology 50, 415-439.

Deb, S.P. \& Fukuoka, M., 1998. Fe-illites in a Proterozoic deep marine slope deposit in the Penganga Group of the Pranhita Godavari valley: their origin and environmental significance. Journal of Geology 106, 741-749.

De Raaf, J.F.M., Boersma, J.R. \& Van Gelder, A., 1977. Wave generated structures and sequences from a shallow marine succession. Lower Carboniferous County Cork, Ireland. Sedimentology 24, 451-483.

Enos, P., 1977. Flow regimes in debris flow. Sedimentology 24, 133-142.

Fisher, R.V., 1981. Flow transformation in sediment gravity flows. Geology 11, 273-274.

Ghosh, S.K. \& Lahiri, S., 1990. Soft sediment deformation by vertical movement. Indian Journal of Earth Science $17,23-43$.

Gopalan, K., Kumar, A., Kumar, S. \& Vijayagopal, B., 2013. Depositional history of the Upper Vindhyan succession, central India: time constraint from $\mathrm{Pb}-\mathrm{Pb}$ isochron ages of its carbonate components. Precambrian Research 233, 103-117.

He, B., Qiao, X., Jiao, C., Xu, Z., Cai, Z., Guo, X., Zhang, Y. \& Zhang, M., 2014. Paleo-earthquake events in the late Early Palaeozoic of the central Tarim Basin: evidence from deep drilling cores. Geologos 20, 105-123.

Horita, J., Zimmermann, H. \& Holland, H.D., 2007. Chemical evolution of seawater during the Phanerozoic: implications from the record of marine evaporites. Geochimica et Cosmochimica Acta 66, 3733-3756.

Kumar, S., Schidlowski, M. \& Joachimski, M.M., 2005. Carbon isotope stratigraphy of the Palaeo-Neoproterozoic Vindhyan Supergroup, central India: implications for basin evolution and intrabasinal correlation. Journal of the Palaeontological Society of India 50, 65-81.

Kump, L.R., 2008. The role of seafloor hydrothermal systems in the evolution of seawater composition during the Phanerozoic. [In:] R.P. Lowell, J.S. Seewald, A. Metaxas \& M.R. Perfit (Eds): Magma to microbe: modeling hydrothermal processes at ocean spreading centers. Geophysical Monograph Series American Geophysical Union 178, 275-283. 
Lowe, D.R., 1975. Water escape structures in coarsegrained sediments. Sedimentology 22, 157-204.

Malone, S.J., Meert, J.G., Banerjee, D.M., Pandit, M.K., Tamrat, E., Kamenov, G.D., Pradhan, V.R. \& Sohl, L.E., 2008. Paleomagnetism and detrital zircon geochronology of the Upper Vindhyan sequence, Son Valley and Rajasthan, India: a ca. 1000 Ma closure age for the Purana basins? Precambrian Research 164, 137-159.

Moretti, M. \& Van Loon, A.J., 2014. Restrictions to the application of 'diagnostic' criteria for recognizing ancient seismites. Journal of Palaeogeography 3, 13-24.

Nagtegaal, P.J.C., 1963. Convolute lamination, metadepositional ruptures and slumping in an exposure near Pobla de Segur (Spain). Geologie en Mijnbouw 42, 363-374.

Odin, G.S. \& Matter, A., 1981. De glauconiarum origine. Sedimentology 28, 611-641.

Orti, F., Rosell, L. \& Anadon, P., 2003. Deep to shallow lacustrine evaporites in the Libros Gypsum (southern Teruel Basin, Miocene, NE Spain): an occurrence of pelletal gypsum rhythmites. Sedimentology 50, 361386.

Owen, G., 1996. Experimental soft-sediment deformation: structures formed by the liquefaction of unconsolidated sands and some ancient examples. Sedimentology 43, 279-293.

Owen, G., Moretti, M. \& Alfaro, P. (Eds), 2011. Recognising triggers for soft-sediment deformation: current understanding and future directions. Sedimentary Geo$\log y 235,3 / 4$.

Perucca, L.P., Godoy, E. \& Pantano, A., 2014. Late Pleistocene-Holocene earthquake-induced slumps and soft-sediment deformation structures in the Acequion River valley, Central Precordillera, Argentina. Geologos 20, 147-156.

Ray, J.S., 2006. Age of the Vindhyan Supergroup: a review of recent findings. Journal of Earth System Science 115, 149-160.

Ray, J.S., Veizer, J. \& Davis, W.J., 2003. C, O, Sr and Pb isotope systematics of carbonate sequences of the Vindhyan Supergroup, India: age, diagenesis, correlations and implications for global events. Precambrian Research 121, 103-140.

Sanders, J.E., 1960. Origin of convolute lamination. Geological Magazine 97, 409-421.

Sarkar, S., Chakraborty, P.P. \& Bose, P.K., 1994. Multimode generation of carbonate tabular intraclast deposits: unnamed Proterozoic formation, Maharastra. Journal of the Geological Society of India 43, 415-423.

Sarkar, S., Banerjee, S. \& Chakraborty, S., 1995. Synsedimentary seismic signature in Mesoproterozoic Koldaha Shale, Kheinjua Formation, central India. Indian Journal of Earth Science 22, 158-164.

Sarkar, S., Chakrabarty, P.P. \& Bose, P.K., 1996. Proterozoic Lakheri (Bhander) Limestone, central India: faci- es, paleogeography and physiography. [In:] A. Bhattacharya (Ed.): Recent advances in Vindhyan geology. Memoir of Geological Society of India 36, 5-26.

Sarkar, S., Chakraborty, P.P., Bhattacharyya, S.K. \& Banerjee, S., 1998. C-12 enrichment along intraformational unconformities within Proterozoic Bhander Limestone, Son Valley, India and its implications. Carbonates and Evaporites 13, 108-114.

Sarkar, S., Chakraborty, S., Banerjee, S. \& Bose, P.K., 2002. Facies sequence and cryptic imprint of sag tectonics in late Proterozoic Sirbu Shale, central India. [In:] W. Altermann \& P. Corcoran (Eds): Precambrian sedimentary environments: a modern approach to ancient depositional systems. International Association of Sedimentologists Special Publication (Blackwell Science) 33, 369-382.

Seth, A., Sarkar, S. \& Bose, P.K., 1990. Synsedimentary seismic activity in an immature passive margin basin, lower member of Katrol Formation, Upper Jurassic, Kutch, India. Sedimentary Geology 68, 279-291.

Seilacher, A., 1984. Sedimentary structures tentatively attributed to seismic events. Marine Geology 55, 1-12.

Seilacher, A., 2001. Concretion morphologies reflecting diagenetic and epigenetic pathways. Sedimentary Geo$\log y$ 143, 41-57.

Üner, S., 2014. Seismogenic structures in Quaternary lacustrine deposits of Lake Van (eastern Turkey). Geo$\log 0 s$ 20, 79-87.

Valente, A., Ślączka, A. \& Cavuoto, G., 2014. Soft-sediment deformation in Miocene deep-sea clastic deposits (Cilento, southern Italy). Geologos 20, 67-78.

Van Loon, A.J., 2009. Soft-sediment deformation structures in siliciclastic sediments: an overview. Geologos 15, 3-55.

Van Loon, A.J., 2014a. The life cycle of seismite research. Geologos 20, 61-66.

Van Loon, A.J., 2014b. The Mesoproterozoic 'seismite' at Laiyuan (Hebei Province, E China) re-interpreted. Geologos 20, 139-146.

Van Loon, A.J. \& Pisarska-Jamroży, M., 2014. Sedimentological evidence of Pleistocene earthquakes in NW Poland induced by glacio-isostatic rebound. Sedimentary Geology 300, 1-10.

Van Loon, A.J., Han, Z. \& Han, Y., 2013. Origin of the vertically orientated clasts in brecciated shallow-marine limestones of the Chaomidian Formation (Furongian, Shandong Province, China). Sedimentology 60, 1059-1070.

Venkateshwarlu, M. \& Rao, J.M., 2013. Palaeomagnetism of Bhander sediments from Bhopal inlier, Vindhyan Supergroup. Journal of the Geological Society of India 81, 330-336.

Manuscript submitted 11 January 2014 Revision accepted 10 April 2014 